\title{
Analysis Of Health Care Quality Evaluation Of Patient Satisfaction In Health District Genyemdistrik Nimboran Jayapura
}

\author{
Agustinus Fatem \\ Vince Tebay \\ Risna Wati
}

\begin{abstract}
Health development aims to provide the widest opportunity for the community, and the government has also provided some means or health facilities that can be used by the community in order to Obtain optimal health status and it is manifested Among other things by building health centers throughout Indonesia, This study aims to identify and evaluate the quality of health services performed by health workers to the satisfaction of Patients undergoing treatment at the health center Genyem. This study to analyze the description of the variable quality of services that include: physical evidence, Reliability, Responsiveness, Assurance and Empathy at the health center in simultaan Genyem and partially significant to satisfaction of Patients in health centers Genyem. The Data in this study were Directly Obtained by distributing questionnaires that have been provided. Multiple linear regression analysis to control classical assumption (normality, autorelation and multikolioneritas) Became the main models chosen in research, having escaped the validity and reliability of the instrument can be concluded:

1. Quality of service include: physical evidence, reliability, responsiveness, assurance and empathy in health center Genyem got good perception of the patient;

2. Variable physical evidence, reliability, responsiveness, assurance and empathy simultaneously (together - the same) Significantly Affects patient satisfaction;

3. Based on the SWOT analysis, found the barriers - barriers faced by PHC Chief and Health Officer in terms of improving patient satisfaction and Formulated a strategy - a strategy that can be applied to improve patient satisfaction.
\end{abstract}

Keywords: Satisfaction, Physical Evidence, Responsiveness, Reliability, Security and Empaty

\section{INTRODUCTION}

Health is the key factor of all human activities carried out, therefore, the public must obtain a guarantee from the government that they will always get the health services needed. A healthy society it will make them productive society will grow the regional economy which will indirectly increase local revenue.

, Community health center / health center, are required to provide quality services both in terms of management, resources, facilities and infrastructure so that services are provided in accordance with Standard Operating Procedures (SOP) and give satisfaction to the service user this study, the health center try to do measurement of the level of satisfaction of people to health services in provide quality health care, government Based on the background of the above problems, we can identify the main problem - the principal problems that occurred in 
Health center care Genyem. PHC Genyem have a quality standard of service that is an achievement of the target to meet health standards as formulated and category in their field.

Because of the tenth field moving in a direction in which the determination is ultimately concerned with the level of quality of life of people living with the level of community life more than the death rate.

The problems were identified as follows:

1. People feel uneasy with inadequate equipment at the health center Genyem so that if emergency patients will be referred to the hospital in the district. Jayapura

2. Distance when referring emergency to hospital in Sentani and Jayapura city very much.

3. PHC Genyem still lacks health workers in every field in doing service to the community.

4. Availability of generic medicines available at Health center care Genyem inadequate.

5. Medical equipment in health centers Genyem inadequate, because a lot of medical equipment in disrepair condition, rusty and not sterile.

Research issues as follows:

1. Is there an impact of service quality to satisfaction of health center patients Genyem Nimboran District Jayapura district?

2. How strategies used to improve patient satisfaction in the health center Genyem Nimboran District?

Theory Definition Quality of Service are:

\section{LITERATURE REVIEW}

- Compliance with the requirements / conditions,

- Suitability for use,

- sustainability refinement improvements,

- Free from damage / defects,

- Meeting the needs of customers since the beginning and at any time,

- Do everything correctly since the beginning,

- Something that can be a happy customer.

Quality according to (Joseph M. Juran) as suitability for use (fitness for use), the definition emphasizes the orientation meeting customer expectations. He noted the importance of involving everyone in the process, namely by emphasizing individual conformity to the requirements (top down). W. Edwards Deming; strategy is based on statistical tools, bottomup by empowering employees to solve problems.

The main emphasis of this strategy is the improvement and quality measurement continuously (Tjiptono, 1997: 11-12).

Lovelock (1994: 179) in his book "Product Plus" argued about the quality of service. What is proposed is an interesting idea about how the product when coupled with a service (service) will generate a force, which it the company in achieving even the profile to face the competition. In Lovelock flower diagram is depicted vulnerable points that exist around the core (Core) of a product into the customer ratings. Although the organization is one and have the kind of product that is different, but basically supplement services have in common. Supplements service by Love lock withdrawal as "petals of a flower" is: information, consultation, order taking, hospitality, caretaking, exceptions, billing, and payment. 
Health Care by Azrul Azwar (1988: 40) each efforts held individually or jointly in organizations to maintain and improve health, treat disease and restore the health of individuals, groups, or communities.

\section{Theory of Customer Satisfaction / Society}

Quality of care will be closely linked to the relationship directly providers with customer service, both individually and organizationally. It requires excellent service (service excellence) of provider services. Tjiptono (1998: 58-59) quotes Elhaitammy (1990) revealed that service excellence itself is an attitude or the way employees serving customers in a satisfactory manner. Broadly speaking, there are four key elements in the concept of service excellence, namely:

1. Speed

2. Accuracy

3. Friendliness

4. Comfort

The fourth component is an integrated component so that when any one of these elements does not exist, cannot be considered as service excellence.

Customer satisfaction is formed an enterprise customer ratings in formulating objectives and benefits given services products to meet the needs, desires, customers. Thus, satisfaction occurs because of what is required and expected by customers.

\section{RESEARCH METHODS}

In this study, the method used is a mixed method research (mixed methodology). Mixed methodology resulted in the fact that more comprehensive in researching the research problem, because these researchers have the freedom to use all means of collecting data in accordance with the type of data that quantitative or qualitative is limited to certain types of data collection tool only.

\section{Measurement variable}

In this study, there is one type of a variable is the independent variable, among others: physical ability, reliability, responsiveness, assurance and empathy using scale liqueur.

Table 3.1Skala Likert

\begin{tabular}{|c|c|c|}
\hline appraisal & $\begin{array}{c}\text { The level of } \\
\text { interest }\end{array}$ & $\begin{array}{c}\text { service } \\
\text { performance }\end{array}$ \\
\hline 5 & Very important & Very good \\
\hline 4 & Important & Good \\
\hline 3 & Not too important & Not good \\
\hline 2 & Not important & Not good \\
\hline 1 & Very unimportant & Very Not Good \\
\hline
\end{tabular}

Patient population is all patients who have been registered as a patient at the health center Genyem as many as 22092 people. 


\section{Samples}

In the sampling, the authors use probability sampling technique, the reason this method provides an opportunity, and equal opportunities to be sampled. The sample in this study is the proportion of patients who had been registered as a patient at the health center Genyem.

While the method of taking the sample using the method Slovin (Syofian Siregar, 2013: 51) $\mathrm{e}=$ error in sampling, for example, $10 \%$ then:

samples in this study were 100 respondents $(n=100)$, comprising:

Table 3.4 Sample

\begin{tabular}{|c|c|c|}
\hline types of samples & identification of Samples & $\begin{array}{c}\text { number of } \\
\text { Samples }\end{array}$ \\
\hline 1. & Health Center staff Genyem & 10 people \\
2. & PHC patients Genyem & 90 people \\
\hline \multicolumn{2}{|c}{ Total } & 100 people \\
\hline
\end{tabular}

Key informants are people - people who really understand the issues studied were the Head of Health center care Genyem Nimboran District, Head of Sub Unit, and medical workers to medical and non medical duty at the health center and the community Genyem (patients) who did Genyem treatment at the health center.

\section{Data collection technique}

- Interview (interview).

- Observation

a. Secondary data is data obtained through library research (Library Reseach) is by reading or researching books, magazines or brochures and regulations or materials that are relevant to the issues discussed.

Data analysis tools are;

a. Descriptive analysis, which is part of the statistical study tools, techniques, or procedures used to depict or describe a collection of data or observations that have been made,in other words to explain in detail the answers of the respondents to the question (questionnaire) that have been distributed or shared. As for the overall data that has been analyzed will use the application software SPSS (Statistical Product and Service Solutions).

b. Quantitative descriptive analysis, which describes in detail the results of studies using multiple regression. The relationship between independent variables and the dependent variable is shown by the following equation (Ghozali, 2005):

$$
\mathrm{Y}=\alpha+\beta 1 \times 1+\beta 2 \times 2+\beta 3+\beta 3 \times 4 \times 5 \times 4+5+\beta \mathrm{e}
$$

Where: $\alpha=$ Konstansa

$\beta 1,2,3,4,5$, = Regression coefficient for $\mathrm{Xi}$,

X 1 = Physical Ability

X 2 = Reliability

X 3 = Response

$\mathrm{X} 4$ = Security

X 5 = Empathy 
$\mathrm{Y}=$ Patient Satisfaction

$\mathrm{e}=$ The error rate (errors)

c. Analysis SWOT is form of analysis used by the management company or organization that is systematic and preparation of a solid plan to achieve the objectives of the company or organization. SWOT is Strength (force) that is a situation or condition that is a picture of the strength of an organization or a company today, Weaknesses (weakness), a situation or condition that is a picture of weakness of an organizations of or company, Opportunity (opportunity) that is a situation or condition that is the opportunities that exist on the outer side of an organization or company and the image can provide development opportunities an organization or company in the future, threats (threats), which is a situation or condition that is a picture of the threat of a company or organization in running a business.

\section{Characteristics of Respondents}

\section{DISCUSSION RESULT}

Respondents who filled out questionnaires and answering interview is the people who take medication and health workers in health centers Genyem. The total yield was 100 questionnaires were distributed questionnaires / respondents. In his study of the characteristics of respondents will focus on several factors, among others: (1) Gender, (2) Latest Education, (3) Employment, (4) Income Monthly.

\section{Gender}

The research data on respondents' gender can be presented in the following table:

Table 4.2 Distribusi respondents in terms of gender

\begin{tabular}{|c|c|c|c|}
\hline No. & Composition Gender & $\mathrm{f}$ & $\%$ \\
\hline 1. & Man & 54 & 54 \\
2. & Female & 46 & 46 \\
\hline \multicolumn{2}{|c|}{ Amount } & 100 & 100 \\
\hline
\end{tabular}

Based on the above table the distribution of respondents in terms of gender composition, in which respondents were male gender - men 54 people (54\%) and respondents who were female as many as 46 people (46\%). This indicates that respondents who dominated for treatment at the health center Genyem is the male sex - men. 


\section{Last education}

Table 4.3. Distribution of respondents in terms of education level

\begin{tabular}{|c|c|c|c|}
\hline No. & Latest Education Composition & $\mathrm{f}$ & $\%$ \\
\hline 1. & Not The End SD & 12 & 12 \\
2. & SD & 8 & 8 \\
3. & SMP & 15 & 15 \\
4. & SMU & 44 & 44 \\
5. & Diploma (D1 / D2 / D3) & 7 & 7 \\
6. & S1 & 14 & 14 \\
7. & S2 & - & - \\
8. & S3 & 100 & 100 \\
\hline
\end{tabular}

According to the table above, we can see that respondents who say do not complete primary school as many as 12 people (12\%) and respondents who said complete primary school by 8 people (8\%), and respondents said that the junior high school graduation as many as 15 people $(15 \%)$, as well as respondents who said that graduating high school as many as 44 people (44\%) and respondents who say that it has completed the Diploma of 7 people (7\%), and respondents said that the graduation S1 as many as 14 people (14\%), and no respondents saying graduate S2 and S3.

This indicates that the patient or the respondent who seek treatment at health centers Genyem mostly set high school education as many as 44 people.

\section{Work}

Table 4.4 Distribution of respondents in terms of job

\begin{tabular}{|c|c|c|c|}
\hline No. & Occupational composition & $\mathrm{f}$ & $\%$ \\
\hline 1. & Student / Student & 11 & 11 \\
2. & Government employees & 19 & 19 \\
3. & Private employees & 8 & 8 \\
4. & labor & 5 & 5 \\
5. & entrepreneur & 12 & 12 \\
6. & more & 45 & 45 \\
\hline & Amount & 100 & 100 \\
\hline
\end{tabular}

We can see that by the above table, that the respondent's status as Student / Student of 11 people (11\%) and respondents who worked as a Public Servant many as 19 people (19\%) and respondents who work as private employees as 8 people ( $8 \%$ ) and respondents who worked as a Labor by 5 people (5\%), and the Self Employed respondents who work as many as 12 people $(12 \%)$ and respondents who work in others - others as many as 45 people (45\%). It can 
be seen that the respondents or patients seeking treatment at health centers by those who eyed other searches.

\section{Income Monthly}

Table 4.5 Distribution of respondents in terms of monthly income

\begin{tabular}{|c|l|c|c|}
\hline No. & \multicolumn{1}{|c|}{ Monthly income } & $\mathrm{f}$ & $\%$ \\
\hline 1. & $<$ idr. 2,200,000 & 58 & 58 \\
2. & $>$ idr. 2,200,000 - idr. 5,000,000 & 35 & 35 \\
3. & $<$ idr 5,000,000 - & 7 & 7 \\
4. & idr. 10,000,000 & - & - \\
\hline \multicolumn{2}{|c|}{ Amount } & 100 & 100 \\
\hline
\end{tabular}

We can see that by the above table, that respondents monthly income $<$ USD. 2,200,000 were 58 05ang 58, and respondents said that income per month> IDR. 2,200,000 - IDR 5,000,000 as many as 35 people, and respondents who say income per month <IDR. 5,000,000 IDR. 10,000,000 of 7 people (7\%). It can be seen that the respondents or patients seeking treatment at Health center care average - average income per month is <IDR. 2,200,000.

\section{Validity and Reliability}

The data processing aims to analyze the influence of the variables of the study. In this section will be presented test data quality with test reliability and validity, and hypothesis testing using regression analysis and analyzed by SPSS.

\section{Classic assumption test}

A linear regression model that has more than one free or independent variables is called multiple regression model. before making multiple regression first performed classical assumption. Classic assumption test consisting of three (3) kinds of testing, namely:

\section{Test multicolinearity}

Table 4:55 Testing Output Magnitude VIF and Tolerance

coefficients a

\begin{tabular}{|ll|r|r|}
\hline Model & \multicolumn{2}{|c|}{ collinearity Statistics } \\
\cline { 3 - 4 } & & \multicolumn{1}{|c|}{ tolerance } \\
\hline \multirow{2}{*}{ (Constant) } &, 772 & \\
& Tengibles_X1 &, 699 & 1,296 \\
1 & Reliablity_X2 &, 860 & 1,431 \\
& Responsiveness_X3 &, 679 & 1,162 \\
& Assurance_X4 &, 831 & 1,472 \\
& Empaty_X5 & & 1.203 \\
\hline
\end{tabular}




\section{Dependent Variable: satisfaction. Pasien_Y}

In the table above it can be seen that both variables VIF to be around the number 1, which is 1,296 to tangibels variable, variable reliability is 1,431 , variable responsiveness is 1,162 , ie 1,472 assutance variable and variable empaty is 1.203 . Likewise figure Tolerance approaching 1 is 0.772 for the variable tangibels, 0.699 for the variable reliability, 0.860 for the variable responsiveness, 0.679 for variable assurance and 0.831 for the variable empaty so it can be said that among the variables X1, X2, X3, X4, X5 free of multicolinearity problem.

\section{Test Heteroskesdastisitas}

based on the results of assistance Software SPSS 21, it can be seen from the scatterplot generated test results can be seen that the point - the point is not to form a clear pattern, and the point - the point spread above and below the 0 (zero) on the $\mathrm{Y}$ axis, it is heteroskedastisitas prove not occur.

\section{Normality test}

Normality test results showed that the graph Normal PP of regression standardized residuals describe the distribution of data around a diagonal line and follow the direction of the diagonal line graph, then the regression model used in this study meet the assumption of normality.

\section{Proof First Hypothesis}

\section{HYPOTHESIS TESTING}

Table 4:56 Simultaneous Test Results (Test F) ANOVA a

\begin{tabular}{|c|c|c|c|c|c|c|}
\hline \multicolumn{2}{|c|}{ Model } & $\begin{array}{l}\text { Sum of } \\
\text { Squares }\end{array}$ & Df & $\begin{array}{c}\text { mean } \\
\text { Square }\end{array}$ & $\mathrm{F}$ & Sig. \\
\hline \multirow{3}{*}{1} & Regression & 9.772 & 5 & 1,954 & 36.299 &, $000^{\mathrm{b}}$ \\
\hline & residual & 5.061 & 94 &, 054 & & \\
\hline & Total & 14.833 & 99 & & & \\
\hline
\end{tabular}

a. Dependent Variable: satisfaction. Patient_Y

b. Predictors: (Constant), Empaty_X5, Reliablity_X2, Responsiveness_X3, Tengibles_X1, Assurance_X4

In accordance with the ANOVA test results in Table 4:55 shows the calculated F value of 36.299 with probability 0,000 . Because much keil probability of 0.05 , the regression model can be used to predict satisfaction. thus tangibles, reliability, responsiveness, assurance and empathy simultaneously (together) a significant effect on patient satisfaction in the health center Genyem. 
Partial Test Results Table 4:57 (t test)

coefficients a

\begin{tabular}{|l|r|r|r|r|r|}
\hline \multirow{2}{*}{ Model } & \multicolumn{2}{|c|}{$\begin{array}{c}\text { unstandardized } \\
\text { Coefficients }\end{array}$} & $\begin{array}{c}\text { standardized } \\
\text { Coefficients }\end{array}$ & \multirow{2}{*}{ Sig. } \\
\cline { 2 - 5 } & \multicolumn{1}{|c|}{ B } & Std. Error & \multicolumn{1}{c|}{ beta } & & \\
\hline \multirow{2}{*}{ (Constant) } & 1,524 &, 241 & & 6.332 &, 000 \\
Tengibles_X1 &, 267 & .048 &, 378 & 5.505 &, 000 \\
Reliablity_X2 &, 220 &, 053 &, 298 & 4.141 &, 000 \\
Responsiveness_X3 &, 145 &, 037 &, 257 & 3.953 &, 000 \\
Assurance_X4 &, 199 &, 047 &, 311 & 4.256 &, 000 \\
Empaty_X5 &, 222 &, 045 &, 328 & 4.959 &, 000 \\
\hline
\end{tabular}

Based on t test results in Table 4:57, the only variable tangibels, reliability, responsiveness, assurance and empathy have a level significant $=0,000$ so partial these five variables affect significant to satisfaction of patients in health centers Genyem.

\section{Proof Second Hypothesis}

The second hypothesis states Suspected dimension tangibels dominant influence on patient satisfaction in the health center Genyem. Based on the above table with a coefficient of 5.505 significant value for the variable tangibels 0,000 partially dominant influence on patient satisfaction in the health center Genyem when compared with other variables.

\section{Linear Regression Testing}

Furthermore, based on multiple linear regression analysis resulted in the regression equation as follows:

$$
Y=1.524+0.267+0.220 \mathrm{X} 1 \mathrm{X} 3 \mathrm{X} 2+0.145+0.199+0.222 \mathrm{X} 4 \mathrm{X} 5
$$

From the equation then the value of regression coefficient for the variable tangibels (X1) equal) 0.267 variable reliability (X2) of 0.220 variable responsiveness (X3) amounted to 0,145 variable assurance (X4) of 0,199 and a variable empathy (X5) is 0.222 this value indicates the effect variable tangibels, reliability, responsiveness, assurance and empathy toward the patient satisfaction is positive.

The test results tangibels determinant of relationship, reliability, responsiveness, assurance and empathy shown by the strong correlation between variables supported by the value of coefficient of determination (Adjusted R Square) amounted to 0,641, which means that 64.1\% satisfaction variables as the dependent variable can be affected by variables tangibels, reliability, responsiveness, assurance and empathy remaining balance of $35.9 \%$ is influenced by other variables outside variables studied.

\section{Effect of Patient Satisfaction Quality of Service}

\section{DISCUSSION}

Based on the results of statistical analysis showed that tangibels, reliability, responsiveness, assurance and empathy simultaneously (together) significantly affects patient satisfaction in the health center Genyem District Nimboran and variable tangibels partially dominant influence on patient satisfaction in the health center Genyem District Nimboran. 
The conclusion of this study support previous research conducted by Anjar Rahmulyono (2008), with the title "Analysis of Effect of Service Quality Patient Satisfaction Health Center in Depok I Sleman". Dimension used in the study are based on the dimensions of service quality consists of variable - variable : reliability, responsiveness, assurance, empathy, and tangible as well as patient satisfaction.

From the research fact that patient satisfaction in the health center Nimboran District Genyem most dominantly influenced by variables tangibels. In connection with the influence of tangibels is the health center Genyem District Nimboran do not in terms of buildings physical, equipment, cleanliness of the room so that the patient is satisfied, health centers perform total service means being able to provide services from the early patients come to completion given that patients were satisfied with the services which are given.

\section{Efforts Improving Patient Satisfaction as follows:}

a. Tangibels (physical facilities), in an effort to demonstrate the performance of the health center to the patient Genyem Nimboran District has been providing comfortable facilities with good interior design, equip with appliances with high-tech equipment and also to ask officers were always tidy in serving customers.

b. Reliability (reliability), in order to ensure the reliability of the services the health center Genyem Nimboran District, nurses and doctors have the knowledge and skill in providing the service of patients with accurate, timely, so that patients feel satisfied.

c. Responsiveness (Responsiveness), in an effort to improve communication between health center staff Genyem District Nimboran with the patient, the type of services that should be provided is determined by attitude, profession and response to patient complaints Responsiveness shown to the patient are: appearance and facial features in giving services to patients, control, finesse and skill of the personnel in providing care for patients and the response of the health centers for services provided.

d. Assurance (Security), in order to provide collateral in the form of a convincing attitude, motivation shown, the suitability of the various services that would give a special value that can be believed by every patient on the quality of services provided.

e. Empathy (Empathy), in an effort to foster loyalty to the PHC services Genyem Nimboran District patient satisfaction in inter personal communication services by increasing personnel (nurses) with patients with understand what is needed by the patient in terms of information technology and modern tools.

\section{SWOT ANALYSIS}

Based on the description of variable data and interviews with Head of Health center care Genyem Nimboran District, it can be formulated factors - factors that can increase patient satisfaction Genyem treatment at the health center, both that of the external and internal environment, among others:

\section{Internal Environmental Factors}

Factors - factors that can increase patient satisfaction (strengths and weaknesses) within the scope of the internal environment is as follows:

\section{Strength (strengths), among others:}

1. PHC Genyem have a doctor who is quite experienced in dealing with patients.

2. PHC Genyem have enough health workers and can services. 
3. Genyem Health Center building has a fairly extensive and sufficient to carry out the treatment to the patient.

4. Poly services there are quite a lot, among others: Poly Midwifery, ER (Emergency Room), Space Operations, Nutrition, Tuberculosis Poli, patient wards, Pharmacy, Public Poli, Poli Gigi, Loket.

5. Genyem Health center care Health center care Plus is one that is in Kanbupaten Jayapura.

6. There are dormitories for health workers who live far away from health centers Genyem.

7. Officers were able to work together with other officers.

\section{Weaknesses (weaknesses), among others:}

1. The distance between the hospitals and health centers so far, so the clerk had trouble referring patients Emergency

2. Existing equipment at the health center Genyem has been much damaged and rusty so in the services to the patients as insufficient.

3. Lack of adequate equipment in every in Health center care Genyem.

4. The shortage of doctors on duty at the health center Genyem

5. There are health workers who often came late.

6. There are still health workers who often get home before curfew, this is because the place they live very far and taxis are there very limited.

7. Place of residence Doctors and health workers on duty at the health center Genyem very far, but it is not a barrier to their task.

\section{External Environmental Factors}

Factors - factors that can increase patient satisfaction (opportunities and threats) within the scope of the external environment is as follows:

\section{Opportunities, among others:}

1. The number of activities undertaken for the development of human resources particularly for health workers on duty at the health center Genyem.

2. Programs and activities funded by and Operational Support Health (BOK).

3. PHC Genyem is Health center care Plus.

4. Threats (Threats), among others:

5. Less conscious about healthy lifestyles

6. Less conscious about the cleanliness of the health center while doing the treatment.

7. The population in Health center care Genyem ie Nimboran District very much.

8. There are elements - elements that interfere with the drunk guy at the health center Genyem

After the SWOT analysis in the matrix above, it can be explained alternate - alternative strategies used to improve patient satisfaction at Genyem health centers, namely:

\section{Alternative strategies So (Strengths - Opportunities)> Comparative Advantage}

The alternative strategy is a combination of two elements which become advantages when used with a bath will give satisfaction to patients undergoing treatment at the health center Genyem.

Alternative strategies to maximize strengths and take advantage of opportunities, namely: 
1. In the services expected the doctor on duty had to take medication properly, so that patient satisfaction increases.

2. The existence of an experienced physician when juxtaposed with the opportunity Health center care Plus it will improve patient satisfaction.

3. Health officials are able to cooperate with other officers when juxtaposed with their activities BOK funds, it will motivate health workers to improve performance to achieve high patient satisfaction.

\section{Alternative strategies ST (Strengths - Threats)> Mobilization}

The alternative strategy is an interaction between and threats, by doing resource mobilization effort which is the power to soften the threat from the outside, and even turn the threat into an opportunity.

\section{Alternative strategies to maximize strength and weaken threats are:}

1. Health workers who have a lot of knowledge and experience and is able to cooperate with other officers are the force that can be used to educate the public about healthy lifestyles.

2. Health care workers who have experience of the power to reduce the elements elements of drunk people who compromise the security of health centers.

3. Building health centers and contained in primary health care is the power to be used in addressing the number in the working area health centers.

\section{Alternative strategies WO (Weaknesses - Opportunities)> Divestment/investmen}

The alternative strategy is the interaction between weakness and pelung outer epidermis which is based on the utilization of the existing opportunities in ways that minimize weaknesses.

Alternative strategies to take advantage of opportunities in ways that minimize weaknesses, among others:

1. The distance between the hospitals and clinics so much so that the workers have difficulties when referring emergency department patients, it was a weakness, it can minimize these by exploiting opportunities by procuring transportation such as ambulances financed under BOK.

2. The existing equipment in the clinic is not adequate and many equipment were damaged, it was a weakness, therefore, to do repairs and procurement of equipment - a new tool to take advantage of the opportunities being funded by the BOK.

3. Place of residence doctors and health workers were very much a weakness, hence the need for the procurement of transportation such as buses health workers can be on time, it can take advantage of opportunities BOK funds.

4. Still the health workers who lack discipline, it was a weakness. The weakness addressed by improving technology by providing absent online, it can be used to take advantage of their opportunity BOK funds.

\section{Alternative strategies WT (Weaknesses - Threats)> Damage Control}

The alternative strategy is the weakest conditions for a meeting between weaknesses and threats from the outside. The strategy that should be taken is to control the loss in order not to become defensive and try to minimize weaknesses and avoid threats.

Alternative strategies to minimize weaknesses and avoid the threats are: 
1. There are still people who are less aware of a healthy lifestyle is a threat, requiring health care providers to improve health education to the community.

2. Enhance awareness of health workers duties and responsibilities in providing health services so that people can enjoy the satisfaction high against the ministry.

3. Providing security awake from the elements - elements of people who disrupt order clinic.

\section{CONCLUSION}

a. In conclusion, simultaneous results of this study prove the allegations hypothesis $\mathrm{H}_{0}$ is rejected and $\mathrm{H}_{1}$ accepted, namely that the Tangible, Reliability, Responsiveness, Assurance, Empathy simultaneously a significant positive effect on patient satisfaction with PHC Genyem Nimboran District Fcount 36.299. Significant value 0,000.

all the variables of service quality dimensions (Tangible, Reliability, Responsiveness, Assurance, Empathy) together have a positive and significant impact on patient satisfaction PHC Genyem Nimboran District.

These results suggest that the alternative hypothesis $(\mathrm{Ha})$ is unacceptable and null hypothesis (Ho) is rejected, its influence is greatest variable Tangible (0.267) followed Empathy (0.222), Reliability $(.220)$, Assurance $(0,199)$ Responsiveness $(0,145)$ against complacency patient. The result is R2 (0641) show that $64.1 \%$ variable patient satisfaction can be explained by the service quality that is Tangible, Reliability, Responsiveness, Assurance, Empathy while the remaining $35.9 \%$ is explained by other variables not included in this research model.

so that the quality of service that gives effect to increase customer satisfaction through:

a. Physical evidence continues to be improved by equipping modern equipment.

b. Constantly improved reliability by serving the consumers are not discriminatory.

c. Responsiveness constantly improved level of understanding of a manager in showing a good attitude in serving consumers.

d. Warranty continues to be enhanced by demonstrating a commitment expectation satisfactory service to consumers.

e. Empathy be improved by showing the attitude and awareness to serve every customer.

It is recommended that the dimensions of service quality by responsiveness that showed a significant effect of weak to be a concern with providing reliable staff, provide fast service and not favoritism, which have an impact on patient satisfaction.

\section{BIBLIOGRAPHY}

Arikunto, Suharsimi. Practice Research Approach procedure. Rineka Copyright 2010.

Azwar, Azrul. 1988. Introduction to Health Administration. Jakarta: PT Binarupa Script.

Azwar, Azrul. (1995). Maintaining Service Quality Program. Jakarta: Yayasan Publisher IDI.

Hamidi. 2004. Qualitative Research Methods: A Practical Application Proposal Preparation and Research Report . Malang: UMM Press. It 14-16

Lyhe, John F, 1996, Ways to satisfy the customer , Abdi grafts. Jakarta.

Nazir, Mohammad (2003). Research Methods , Jakarta, Publisher Ghalia Indonesia

Nursalam (2011). Nursing Management . Jakarta. Publisher Salemba Medika 
Tebay, V., Fatem, A., \& Wati, R. (2017). Analysis Of Health Care Quality Evaluation Of Patient Satisfaction In Health District Genyemdistrik Nimboran Jayapura. Advances in Social Sciences Research Journal, 4(7) 139-152.

Pamudji, 1994. Quality of Health Care in primary Beringin Semarang regency. Dissertation. Semarang: Undergraduate Program Diponegoro University.

Ratminto and Atik Septi Winarsih. 2006. Service Management. Yogyakarta: Student Library.

Ratminto and Atik Septi Winarsih. 2006. Service Management. Yogyakarta: Student Library.

Rino DeSanto 2011. Quality of Service Health Center in the City of Madison. Unpublished dissertation. Madiun: Research Report

Saefullah, 1999. Quality of Health Care in primary Beringin Semarang regency. Dissertation. Semarang: Undergraduate Program Diponegoro University.

Schiffman, Leon G Leslie L. Kanuk (2007). Consumer Behavior .Jakarta: Index

Sedarmayanti, 1999. Quality of Health Care in primary Beringin Semarang regency. Dissertation. Semarang: Undergraduate Program Diponegoro University.

Singarimbun, Masri and Sofian Effendi. 1995. Research Methods Survey. Jakarta: LP3ES.

Sugiyono.1994. Methods of Administrative .Bandung: Alfabeta

Sugiyono. 2012. Quantitative Research Methods Qualitative and R \& D. Bandung: Alfabeta.

Suharsimi Arikunto. 2010. Research Procedure A Practical Approach . Jakarta: Rineka Reserved.

Tjiptono, Fandy, 2000. Management Services, Second Edition, Andy Offset. Jakarta

Minister for Administrative Reform Decree No. KEP / 25 / M.PAN / 2/2004 on General Guidelines for Preparation of Public Satisfaction Index Service Unit Government Agencies.

Regulation of the Minister of Health of the Republic of Indonesia Number 75 Year 2014 About the Center for Public Health

Thesis

Christa V. Urbinas. 2014. Analysis of Service Quality Customer Satisfaction At Telkomsel Grapari Jayapura. Unpublished Dissertation Jayapura: Cenderawasi University Graduate School.

Cut Zuliati Muli 2009. Influence of Quality of Health Care Inpatient Satisfaction In Health center care Medan. Unpublished Dissertation Terrain: Graduate School of Public Health Sciences University of North Sumatra.

Sugiman 2014. Influence of Service Quality Regional Water Company Customer Satisfaction In the city of Jayapura. Unpublished Dissertation Jayapura: Cenderawasih University Graduate School. 